\title{
DIGITALISASI EKONOMI SYARIAH: PENERAPAN HUKUM-HUKUM ISLAM DALAM JUAL BELI ONLINE
}

\author{
Oleh: \\ Safira Dhea Fitriani ${ }^{1}$, Margi Rizki Satriani Mㄹ $^{2}$ Titin Retnosari ${ }^{3}$, Nur Rohmahwati ${ }^{4}$, \\ ${ }^{1}$ Universitas Jember, safiradhea31@gmail.com \\ ${ }^{2}$ Universitas Jember, margirizki2@ gmail.com \\ ${ }^{3}$ Universitas Jember, retnosari.titi9@gmail.com \\ ${ }^{4}$ Universitas Jember nurrohmawati58@gmail.com
}

Abstract

Technological developments have penetrated into all fields, including buying and selling. In the past, buying and selling activities required sellers and buyers to meet face to face to reach an agreement, in contrast to the current era where technology is increasingly advanced where sellers and buyers do not have to meet in person but the buying and selling process can still take place. This activity is commonly referred to as buying and selling online, where the process takes advantage of the internet network. In Islam this is something new, but that does not mean that this activity is prohibited, as long as it does not violate Islamic principles. This study tries to identify the implementation of Islamic principles in online buying and selling activities both from the products sold and the transaction process. This study uses qualitative research by taking informants from online business owners in Banyuwangi, Gresik and Kediri by indirect interview. The result of this study was all online business actors did tried applying Islamic sharia in the practice of transaction by social media as Whatsapp, Instagram and Facebook and e-marketplace.

Keywords: Buying and selling online, Islamic principles

\section{Abstrak}

Perkembangan teknologi merambah ke semua bidang, tak terkecuali dengan jual beli. Jika dulu aktivitas jual beli mengharuskan penjual dan pembeli bertemu langsung untuk mencapai kesepakatan, berbeda dengan era sekarang dimana teknologi semakin maju dimana penjual dan pembeli tidak harus bertemu langsung namun proses jual beli tetap bisa dilangsungkan. Kegiatan tersebut biasa disebut dengan jual beli online, dimana prosesnya memanfaatkan jaringan internet. Dalam Islam hal ini menjadi hal yang baru namun bukan berarti kegiatan ini dilarang, selama didalamnya tidak melanggar kaidah-kaidah Islam. Penelitian ini mencoba untuk mengidentifikasi pelaksanaan kaidah-kaidah Islam dalam kegiatan jual beli online baik dari produk yang dijual dan proses transaksi. Penelitian ini menggunakan penelitian kualitatif dengan mengambil informan dari para pemiliki usaha online yang ada di Banyuwangi, Gresik dan Kediri melalui wawancara tidak langsung. Hasil dari penelitian ini adalah para pelaku usaha online mencoba menerapkan syariat Islam dalam bertransaksi melalui media sosial seperti Whatsapp, instagram dan facebook, dan marketplace online.

Kata kunci: Jual beli Online, kaidah Islam 


\section{PENDAHULUAN}

Manusia sebagai makhluk sosial selalu membutuhkan bantuan orang lain dalam kehidupan sehari harinya, tidak terkecuali dalam menjalankan kegiatan ekonomi. Kegiatan ekonomi seperti jual beli, sewa menyewa, dan melakukan pinjaman. Kegiatan perekonomian atau muamalah ini dalam agama Islam memiliki aturan aturan tertentu yang diperuntukkan untuk kemaslahatan umum. Dengan teraturnya muamalah, maka kehidupan manusia jadi terjamin dengan sebaik baiknya dan teratur dengan minimnya penyimpangan penyimpangan yang dapat merugikan. Salah satu bentuk muamalah yang diperbolehkan dalam Islam adalah jual beli. Jual beli merupakan salah satu jenis kegiatan yang sering dilakukan oleh manusia dalam kehidupan sehari hari yang dilakukan atas dasar suka sama suka. Dalam artian lain jual beli merupakan perpindahan hak atas suatu barang atau jasa dari penjual ke pembeli dengan dasar suka sama suka. Perilaku ekonomi ini (jual-beli) sudah terbentuk sejak manusia membutuhkan individu lain yang memiliki barang atau jasa yang tidak dimilikinya, sedangkan ia membutuhkannya. Nabi Muhammad SAW sendiripun telah menyatakan bahwa 9 dari 10 pintu rezeki adalah melalui perdagangan. Artinya, melalu jalan perdagangan atau jual beli inilah, pintu pintu rezeki akan dapat dibuka sehingga karunia Allah terpancar daripadanya. (Munir, 2017) Dalam Al-Qur'an Surat Al Baqoroh ayat 275, Allah menegaskan bahwasanya “.... Allah menghalalkan jual beli dan mengharamkan riba”. Yang menarik dari ayat tersebut adalah Allah mengharamkan riba tetapi didahului dengan penghalalan jual beli, dengan syarat dilakukan sesuai dengan ajaran Islam. Dalil diatas diperuntukkan untuk jual beli secara konvensional atau offline. (Fitria, 2017).

Bentuk jual beli mengalami perkembangan sesuai dengan perkembangan masyarakat dan perubahan sosial. Masyarakat primitive dalam melakukan jual beli mengambil bentuk tukar menukar barang yang tidak sejenis atau barter. Pada perkembangan selanjutnya sistem barter ini mulai ditinggalkan karena manusia mulai mengenal uang sebagai alat tukar-menukar. Kita mengenal dua cara yang dilakukan dalam jual beli, yaitu secara konvensional dan secara modern. Cara konvensional atau offline ini dilakukan dengan saling bertemunya pembeli dan penjual dan baik keduannya dapat melalukan akad secara langsung. Cara modern atau lebih dikenal dengan sistem online, secara garis besar dapat diartikan sebagai jual beli barang dan jasa melalui media elektronik, khusunya melalui internet atau secara online ${ }^{2}$. Di setiap kali orang berbicara mengenai belanja online, mereka memahami bahwa internet merupakan media utama dalam proses atau mekansisme jual beli. Fenomena sistem jual beli online sekarang ini banyak melibatkan pihak ketiga atau marketplace sebagai tempat bertemunya penjual ataupun pembeli. Marketplace yang cukup terkenal seperti Lazada, Shopee, Tokopedia, namun juga tidak sedikit yang menggunakan media sosial sebagai media jual beli. Dari penjelasan diatas dapat di lihat bahwa yang membedakan jual beli offline dengan jual beli online yaitu proses transakaksi atau akad dan media utama dalam proses tersebut. Dari penjelasan diatas dapat di lihat bahwa yang membedakan jual beli offline dengan jual beli online yaitu proses transakaksi atau akad dan media utama dalam proses tersebut. Transaksi online sering kalinya terdapat praktik kecurangan, dimana penjual dan pemebli tidak bersikap jujur. Seringnya pembeli tidak mengirimkan barang atau barang yang dikirim tidak sesuai dengan spesifikasi. Pembeli terkadang melakukan cancel barang saat barang dalam proses kirim tanpa alasan yang jelas, tak jarang pembeli juga enggan untuk membayar barang ketika barang sampai (sistem COD) (Pekerti, 2018).

Dengan semekin banyaknya media untuk melakukan jual beli online, kita juga perlu tahu apa perbedaan dari online shop, marketplace dan e-commerce. persamaan dari ketiga hal 
tersebut adalah sama-sama menjual barang melalui media internet. Online shop atau toko online adalah system belanja online dimana pembeli dapat berinteraksi dan menanyakan apapun mengenai produk kepada penjual dengan melalui media sosial seperti WhatsApp, Instagram, Facebook, Line, dan lain sebagainya. Sedangkan marketplace adalah dimana para produsen atau penjual diberikan tempat untuk menjual produk-produknya. Marketplace ini lebih seperti wadah bagi para penjual online untuk berjualan dan diberikan fasilitas untuk transaksi seceara online dan hanya membantu untuk mempromosikan barang saja, contohnya seperti shopee, tokopedia, dan lain sebagainya. Dan untuk e-commerce adalah produsen dari sebuah produk telah memiliki portal online atau website mereka sendiri untuk mereka memperdagangkan produk mereka sendiri, contohnya seperti zalora, dan lain sebagainya (Pratisti, 2015).

Dalam Islam terdapat prinsip-prinsip yang harus diperhatikan dalam jual beli, baik jual beli secara langsung (offline) ataupun jual beli yang dilakukan dengan cara online. Prinsipprinsip tersebut adalah keadilan dan transaksi yang jujur, memenuhi perjanjian dan melaksanan kewajiban antara penjual dan pembeli, memenuhi semua akad yang telah disepakati bersama, halal dan haram dalam transaksi jual beli harus jelas, dan pemasaran yang bebar dan penentuan harga yang wajar. Tentu saja dalam pelaksanaan jual beli online memiliki keunggulan dan kelemahan. Salah satu keunggulannya adalah kita bisa mengakses ataupun hanya sekedar melihat-lihat barang kapanpun dan dimanapun serta tidak perlu bertemu langsung antara penjual dan pembeli. Namun, dibalik kekunggulan tersebut juga terdapat kelemahannya, diantaranya yaitu pembeli tidak mengetahui secara langsung kualitas produk yang dijual serta dikarenakan proses jual beli dilakukan dengan tidak bertemu langsung maka akan meningkatkan angka penipuan baik dari pihak penjual ataupun pembeli (Putra, 2019). Penelitian ini bertujuan untuk melihat bagaimana pelaku usaha online menerapkan hukumhukum Islam dalam proses produksi hingga transaksi antara penjual dan pembeli.

\section{LITERATURE REVIEW}

Untuk menghindari plagiarisme, maka penulis mencantumkan mengenai beberapa penelitian terdahulu sebagai rujukan serta bentuk apresiasi terhadap karya tulis orang lain. Berikut ini beberapa hasil karya yang terdokumentasikan terkait dengan permasalahan yang dikaji oleh penulis, (Syauqi n.d.) meyatakan bahwasannya era ekonomi digital memiliki keunikan tersendiri dibandingkan dengan era sebelumnya. Era ekonomi digital merupaka era yang tidak bisa kita hindari, mengingat semakin banyak orang yang terhubung dengan teknologi. Adanya kemudahan teknologi dalam sektor ekonomi tersebut tentunya diharapkan laju pertumbuhan ekonomi kreatif di Indonesia semakin bertambah dan berkembang. Adapun sumberdaya manusia yang dibutuhkan dalam memajukan ekonomi kreatif adalah berupa kreativitas berupa gagasan ide-ide yang nantinya dapat menghasilkan barang ataupun jasa yang dapat bernilai ekonomi. Kemudahan teknologi tersebut tentunya dapat dimanfatkan untuk mendukung industri kreatif yang sedang dirintis oleh banyak orang, seperti misalnya dalam menyebarkan informasi mengenai produk yang akan dijual ke seluruh penjuru negeri tanpa mengeluarkan biaya yang tinggi. Dengan menggunakan bantuan teknologi maka informasi produk akan lebih cepat tersebar ke seluruh penjuru negeri. Dengan melihat paparan diatas, terlihat bahwa terdapat kesempatan emas mengenai penggunaan startup untuk menunjang ekonomi kreatif yang terus berkembang.

(Ansori 2016) juga menerangkan bahwa digitalisasi ekonomi syariah dapat merambah dalam berbagai aspek ekonomi baik ekonomi mikro maupun ekonomi makro. 
Peran digital pada era sekarang sangat luar biasa, sebab hampir semua perekonomian menggunakan teknologi informasi dan komunikasi atau digitalisasi, baik dalam mengemas produk ataupun dalam memasarkan produk, sehingga lebih mudah dan lebih cepat dalam distribusi informasi yang digunakan untuk membuat pertumbuhan ekonomi semakin cepat dan tiada batas dengan dukungan teknologi digital dan teknologi informasi. Hal tersebut juga harusnya dapat diterapkan pada pelaku UMKM, UMKM memiliki peran besar dalam kehidupan msayarakat kecil untuk megurangi masalah kemiskinan dan pengangguran. Usaha kecil dan menengah atau UMK juga mempunyai peran penting terhadap pertumbuhan dan pembangunan perekonomian nasional. Namun kemajuan teknologi tak serta merta membuat para pelaku UMKM menjadi mudah untuk mengkakses serta menggunakannya. (Lubis 2016) menjelaskan bahwasannya rendahnya pemahaman terhadap pemanfaatan teknologi, rendahnya dukungan pemerintah serta ketersediaan investasi menyebabkan pelaku UMKM masih terkendala dalam memanfaatakan kemudahan teknologi dalam memasarkan produknya.

(Helmalia and Afrinawati 2018) juga memiliki pendapat yang sama, yakni kekurangan pengetahuan teknologi membuat UMKM di Indonesia ketinggalan dalam strategi pemasaran, selain itu juga ditambah degan persaingan antar UMKM yang semakin ketat. Maka dari itu dibutuhkan dorongan baik dari internal maupun eksternal agar para pelaku UMKM mampu bersaing di era digitalisasi ekonomi saat ini. Misalnya saja dalam (Maharani and Ulum n.d.) yang juga menerangkan bahwasannya pelaku UMKM, baik itu yang berbasis syariah maupun tidak, perlu sekali didorong dan dimaksimalkan perannya dalam berdagang melalui teknologi/elektronik. Menurut data survei dari Asosiasi Penyelenggara Jaringan Internet Indonesia (APJII) menyatakan bahwa lebih dari setengah penduduk di Indonesia telah terhubung ke internet. Hal ini memperlihatkan bahwa potensi belanja online dan penggunaan internet sebagai media untuk mempromosikan usaha cukup berkembang di Indonesia. Sehingga hal ini dapat menjadi peluang bagi UMKM untuk menggunakan teknologi informasi sebagai media dalam mengembangkan pasarnya. Maka dari itu pelaku Usaha Mikro Kecil Menengah (UMKM) harus mampu bersaing di tengah digitalisasi ekonomi saat ini, sebab akan semakin banyak pesaing yang menjadi pertimbangan bagi pelaku usaha untuk melakukan inovasi dalam memenangkan persaingan tersebut. Apalagi, di era persaingan ini, pelaku UMKM seharusnya melek akan teknologi informasi (TI) agar dapat memudahkan memasarkan produk hingga ke luar negeri (Febriyantoro and Arisandi 2018).

Ekonomi digital merupakan fenomena baru yang muncul seiring dengan perkembangan teknologi yang semakin maju. Dalam penggunaannya, ekonomi digital dapat digunakan pada lingkup mikro dan makro dan umumnya di era sekarang dikenal dengan nama e-commerce. Konsep mengenai ekonomi digital pertama kali diperkenalkan oleh Tapscott (1998), menjelaskan sebuah sosiopolitik dan sistem ekonomi yang mempunyai karakteristik sebagai sebuah ruang intelijen, meliputi informasi, berbagai akses instrumen informasi dan pemrosesan informasi dan kapasitas komunikasi.

Adapun konsep lainnya yang diperkenalkan oleh Zimmerman (2000) dengan konsep yang seringkali digunakan untuk menjelaskan dampak global (keseluruhan) dari adanya teknologi informasi dan komunikasi terhadap ekonomi. Konsep ini juga dapat memberikan penjelasan mengenai dampak dari adanya inovasi teknologi terhadap ekonomi digital degan 
lingkup ekonomi mikro maupun makro. Dalam keseluruhan sistem penjualannya, tentu saja ekonomi digital amat sangat bergantung pada teknologi digital yang ada.

\section{METODE PENELITIAN}

\section{Jenis dan Pendekatan Penelitian}

Pada penelitian yang peneliti lakukan mengenai penjualan barang berbasis online atau tepatnya online shop, tepatnya di beberapa daerah di Jawa Timur. Peneliti menggunakan jenis pendekatan Fenomenologi. Studi Fenomenologi merupakan pendekatan penelitian yang mencoba menggali serta menemukan pengalaman hidup manusia terhadap diri dan hidupnya.

Dalam penelitian ini peneliti melihat, dan mengamati peristiwa yang diteliti. Peneliti mencoba memahami setiap makna dari kegiatan yang dilakukan pada saat terjadi transaksi antara penjual atau toko dengan pembeli yang dilakukan secara online. Interpretasi dan pemahaman makna dari realitas mempunyai peran penting dalam penelitian tentang online shop ini. Dalam penelitian ini peneliti berusaha menggali data dengan menyesuaikan keadaan asli tanpa melakukan manipulasi data temuan.

\section{Penentuan Lokasi dan Waktu Penelitian}

\section{Lokasi Penelitian}

Dikarenakan masih dalam masa pandemi, maka lokasi yang dipilih untuk melakukan penelitian adalah derah tempat tinggal dari masing-masing peneliti/penulis. Adapun daerahdaerah yang menjadi lokasi penelitian yaitu Banyuwangi, Gresik dan Kediri.

\section{Waktu Penelitian}

Waktu penelitian diambil dengan melakukan wawancara secara tidak langsung atau menggunakan aplikasi berbagi pesan atau whattsap setiap seminggu sekali secara rutin.

\section{Penentuan Informan}

Penentuan informan dalam penelitian ini adalah dengan menggunakan Criterion sampling. Teknik ini bertujuan untuk mendapatkan informan atau kasus yang sesuai dengan kriteria dari penulisan risat yang telah ditetapkan. Yaitu dengan memilih para pemilik online shop yang menggunakan syariat Islam dan yang tidak.

\section{Teknik Pengumpulan Data}

\section{a. Observasi.}

Observasi merupakan teknik yang digunakan untuk mengumpulkan data penelitian dari lapangan dengan melakukan pengamatan dan pengindraan. Peneliti dituntut untuk dapat melakukan pengamatan dengan detail, mulai dari bahasa tubuh maupun dari cara mereka melakukan aktivitas mereka yang kemudian harus membuat laporan berdasarkan dari apa yang dilihat, didengar, dan dirasakan selama observasi. Observasi dilakukan untuk mendapatkan gambaran yang lebih nyata, agar peneliti dapat menjelaskan keadaan selama penelitian dengan lebih hidup.

\section{b. Wawancara}

Wawancara merupakan salah satu teknik pengumpulan data yang dilakukan dengan mengajukan pertanyaan kepada informan yang sudah dipilih untuk dijadikan sebagai sumber informasi untuk melengkapi data-data di lapangan dari observasi yang telah dilakukan. Wawancara merupakan teknik pengumpulan data yang lebih intens dikarenakan pelaksanaanya akan dilakukan empat mata dengan informan tersebut.

\section{Teknik Analisis Data}


Analisis data merupakan proses berkelanjutan dari semua tahapan-tahapan sebelumnya. Dan pada tahap analisis data ini, peneliti dituntut untuk mengembangkan logika berfikir dari semua peneliti. Analisa data dalam kualitatif dapat dilakukan saat sedang melakukan riset dan pada saat riset tersebut sudah selesai dilakukan. Analisis data dapat dilakukan apabila peneliti sudah mengumpulkan data yang cukup untuk kemudian dianalisis dan menarik kesimpulan.

Dalam analisa data ini, para peneliti kemudian membuat transkrip dari wawancara yang sudah dilakukan secara rutin, kemudian mengelompokkan data-data yang dianggap penting dan membuang data-data yang sekiranya tidak diperlukan dalam riset ini. Data-data yang telah dipilih dan dianggap sesuai kemudian dideskripsikan dan ditarik kesimpulan.

\section{HASIL DAN PEMBAHASAN}

Sebagai makhluk sosial, tentu saja manusia membutuhkan orang lain untuk memenuhi segala kebutuhan hidupnya. Pemenuhan kebutuhan ini dapat berupa pemenuhan kebuhutan ekonomi, sosial, pribadi, dan lain sebagainya. Manusia membutuhkan orang lain untuk memenuhi kebutuhan perekonomiannya dapat dilihat dalam contoh bidang pekerjaan. Manusia tentunya membuthkan pekerjaan untuk memenuhi kebutuhan mereka sehari-hari. Yang dimana tentu saja manusia membutuhkan orang lain untuk bekerja dan mendapatkan upah ataupun memberikan upah. Dalam Islam, bekerja menjadi salah satu keharusan yang harus dilakukan, selain untuk memenuhi kebutuan sehari-hari tetapi juga untuk menjalankan ibadah kepada Allah SWT.

Jenis dan macam-macam pekerjaan sangatlah beragam, apalagi di jaman yang segala sesuatunya sudah dapat didapatkan dengan mudah. Saat ini pekerjaan dapat dilakukan dengan menggunakan media masa dan internet, salah satunya adalah berjualan online atau membuka toko online (Online Shop). Online shop atau toko online menjadi salah satu alternatif bagi beberapa orang untuk memulai usaha mereka. Modernisasi perekonomian adalah hasil dari perubahan-perubahan ekonomi yang diakibatkan oleh perubahan-perubahan yang lebih luas dan fundamental, sehingga tenaga-tenaga kreatif dapat disalurkan kea rah tujuan-tujuan yang lebih produktif. (Geertz, 1977) Karena dengan teknologi yang maju saat ini, orang-orang memanfaatkan hal tersebut untuk pembukaan lahan kerja. Percepatan Globalisasi diperbarui atas aktivitas ekonomi dunia dibantu oleh penggunaan informasi dan komunikasi. (Barker, 2011). Keberadaan media masa dan jaringan internet membawa keberkahan tersendiri bagi banyak orang, tak terkecuali umat muslim. Dalam Islam sendiri jual beli dapat diartikan sebagai menukar harta dengan harta dengan menggunakan cara-cara tertentu. Dalam Islam jual beli yang diridhoi oleh Allah dan Rasulnya adalah jual beli yang di dalamnya tidak mengandung unsur riba. Karena riba adalah suatu hal yang dilarang oleh Allah dan sebisa mungkin kita sebagai umat muslim menjahui hal tersebut. Dalam Al-Quran surah Ali Imron ayat 130 menjelaskan mengenai larangan pedagang atau penjual untuk memakan riba, arti dari ayat tersebut berbunyi, "Hai orang-orang yang beriman, janganlah kamu memakan riba dengan berlipat ganda dan bertakwalah kamu kepada Allah, supa kamu mendapat keberuntungan".

Dalam ayat tersebut jelas dikatakan bahwa riba sangatlah dilarang oleh Allah. Ayat mengenai riba bukan hanya terdapat dalam surah Ali Imron ayat 30 saja, namun masih banyak lain surah dan ayat yang menjelaskan mengenai larangan dan hokum riba. Riba dapat diartikan sebagai pengambilan keuntungan yang berlebih dan membebani atau merugikan salah satu pihak. Mengambil keuntungan memang bukanlah hal yang dilarang dalam berdagang, namun jika keuntungan yang diambil terlalu banyak dan memberatkan salah satu pihak ini sangat dianjurkan untuk tidak dilakukan. Selain larangan riba, dalam Islam masih banyak lagi hal-hal 
yang dapat diperhatikan dalam jual beli, seperti kehalalan produk yang mereka jual. Menurut Muslehuddin, Siddiqi, Chapra, mereka beranggapan bahwa perekonomian yang bertumpu pada suku bunga dapat mengakibatkan terjadinya suatu kesalahan tempat resources yang pada gilirannya akan mengakibatkan ketidakstabilan perekonomian. (Kalsum, 2014)

Hasil dari penelitian ini adalah para pelaku usaha online atau mereka yang memiliki toko usaha online berusaha semaksimal dan semampu mereka dalam menjalankan jual beli yang mereka lakukan dalam koridor agama Islam. Para penjual online ini menjual produk mereka melalui media massa seperti Whatsapp, instagram dan facebook. Dengan perkembangan media jual beli saat ini dikarenakan kemajuan tekhnologi yang sangat pesat tidak menjadikan penjual lantas melupakan apa yang menjadi kewajibannya sebagai seorang muslim dan bagaimana aturan mengenai jual beli online ini. Hal-hal yang diperhatikan dalam proses jual beli ini adalah menjahui riba dan menjaga kehalalan produk.

Sudah dijelaskan diatas bahwasanya Islam sangat mengharamkan riba, untuk itu para penjual atau pedagang online ini berusaha sebisa mungkin untuk menjahui riba. Keuntungan yang mereka ambil tentu saja sudah mereka perhitungan dengan sangat matang dan tentu saja tidak mengandung riba. Mereka sadar bahwa mereka tidak perlu mengambil keuntungan yang besar hingga melakukan riba dikarenakan mereka percaya bahwa rezeki mereka sudah diatur oleh Allah SWT. Membangun kepercayaan dan hubungan yang baik dengan pelanggan menjadi fokus utama mereka. Dalam dunia berdagang tentu saja kepercayaan antar penjual dan pembeli sangatlah penting. Ketika penjual dan pembeli telah membangun kepercayaan diantara mereka maka dapat dipastikan bahwa pembeli akan merasa puas dengan berbelanja di lapak kita dan tidak perlu takut dan khawatir lagi jika ingin berbelanja lagi di toko kita.

Melakukan jual beli online yang dimana produsen dan konsumen tidak bisa betermu langsung dan tidak bisa melakukan akad secara langsung pula. Maka akad akan dilakukan melalui media massa juga dengan menyepekati beberapa hal dimana hal tersebut tidak menyudutkan ataupu merugikan pihak manapun serta kedua belah pihak saling menyetujuinya. Tak jarang apabila pejual dan pembeli berada pada jarak jauh yang dimana harus membutuhkan biaya kirim barang tambahan. Untuk hal ini juga perlu untuk disepakati bersama dikarenakan biaya pengiriman di setiap daerah berbeda-beda tergantung jarak tempuhnya.

Tentu saja sebagai konsumen atau pembeli terkadang meresa was-was mengenai produk yang akan mereka beli, terlebih lagi untuk membeli makanan. Memperhatikan kehalalan bagi seorang muslim sangatlah penting untuk dilakukan. Hal ini tentu saja harus dilakukan dikarenakan sebagai seorang muslim yang taat kita harus menjaga apa yang masuk ke dalam mulut kita, entah itu tentang bagaimana cara memperolehnya ataupun kandungan apa saja yang ada di dalamnya. Bagi seorang konsumen mungkin hal-hal yang paling bisa dilakukan adalah melihat label Halal MUI di kemasan produk dan melihat pula komposisi bahan di balik kemasan. Namun, tidak semua pelaku usaha makanan mencantumkan hal-hal tersebut. Alasannya adalah mereka masih merambah usaha mereka dalam ruang lingkup kecil mereka. Pembelinya adalah mereka yang kenal dan tahu penjualnya, seperti teman sendiri ataupun saudara. Sehingga pembeli hanya mengandalkan pengetahuan mereka tentang penjual saja. Label hanya bertuliskan merek dagangan ataupun sekedar ucapan terimakasih.

Sedangkan bagi penjual, mereka berusaha untuk mendapatkan bahan-bahan untuk usaha mereka (roti) dengan sebaik mungkin serta tingkat kehalalannya. Mutia sebagai perintis usaha roti hal tersebut menjadi hal yang sangat penting untuk dia perhatikan. Selain untuk menjaga kualitas dan kepercayaan pelanggan, hal tersebut juga menyangkut dirinya sendiri. Dia mencoba untuk memposisikan dirinya sebagai seorang pembeli, dimana hakikatnya seorang 
pembeli adalah mencari yang kualitasnya bagus, harga terjangkau serta tentu saja halal. Responden mencoba untuk membeli bahan-bahan kepada orang yang terpercaya serta produk yang dipakai memiliki kualitas yang baik dan tentu saja halal. Usaha yang dijalankan bukan hanya menjual satu jenis usaha roti saja, namun juga rajutan tangan karakter. Jika roti yang dijual oleh. Media sosial dan marketplace menjadi wadah dalam memasarkan produk, dan membuka peluang penjualannya lebih luas. Namun, pengunaan marketplace belum begitu efektif dikarenakan masih terhitung baru dan promosi dlakukan secara organic, sehingga masih sedikit konsumen yang tahu pada produknya serta deskripsi yang kurang menarik menjadi salah satu alasan kurangnya minat pada produk tersebut.

\section{SIMPULAN}

Para pelaku usaha online berusaha melakukan kegiatan jual beli dengan tetap melakukan kaidah-kaidah Islam. Usaha online yang dilakukan tidak menjadi pengahalang untuk melakukan kegiatan jual beli dengan tetap melakukan kaidah-kaidah Islam. Mulai dari menghindari riba, menggunakan bahan-bahan produksi yang terjamin kehalalannya mulai dari cara mendapatkannya hingga cara mengolah atau memproduksinya.

\section{REFERENSI}

Pratisti, R. (2015). Inilah Perbedaan Online Shop, E-Commerce, dan Marketplace Yang Perlu Kaти Ketahui. Retrieved from teknonisma: https://teknonisme.com/inilah-perbedaanonline-shop-e-commerce-dan-marketplace-yang-perlu-kamu-

ketahui/\#: :text=Sistem\%20belanja\%20e\%2Dcommerce\%20hampir,berasal\%20dari\% 20website\%20itu\%20sendiri.

Putra, M. D. (2019). Jual Beli On-Line Berbasis Media Sosial Dalam Perspektif Ekonomi Islam. Iltizam Journal Of Shariah Economic Research, 98-99.

Zuardi, M. H. (n.d.). Bisnis Online Dalam Perspektif Islam. ristekdikti, 9.

Ansori, A. (2016). DIGITALISASI EKONOMI SYARIAH. ISLAMICONOMIC: Jurnal Ekonomi Islam 7(1). doi: 10.32678/ijei.v7i1.33.

Febriyantoro, M. T., and Debby A. (2018). Pemanfaatan Digital Marketing Bagi Usaha Mikro, Kecil Dan Menengah Pada Era Masyarakat Ekonomi Asean.JMD: Jurnal Riset Manajemen \& Bisnis Dewantara 1(2):61-76. doi: 10.26533/jmd.v1i2.175.

Helmalia, H., and Afrinawati A. (2018). "PENGARUH E-COMMERCE TERHADAP PENINGKATAN PENDAPATAN USAHA MIKRO KECIL DAN MENENGAH DI KOTA PADANG.” JEBI (Jurnal Ekonomi dan Bisnis Islam) 3(2):237. doi: 10.15548/jebi.v3i2.182.

Lubis, T. A. (2016). "Pemanfaatan Teknologi Informasi pada Usaha Mikro Kecil dan Menengah di Kota Jambi." 3(3):12.

Maharani, S., and Miftahul U.( n.d). EKONOMI DIGITAL: PELUANG DAN TANTANGAN MASA DEPAN TERHADAP EKONOMI SYARIAH DI INDONESIA. 11.

Syauqi, A. T.( n.d). Startup sebagai Digitalisasi Ekonomi dan Dampaknya bagi Ekonomi Kreatif di Indonesia.5.

Kalsum, U. (2014). Riba dan Bunga Bank dalam Islam.Vol. 7. https://core.ac.uk/download/pdf/231140436.pdf. 9 Januari 2020

Barker, C.(2011).CULTURAL STUDIES. Bantul. Kreasi Wacana 
Geertz, C. (1977). Penjaja dan Raja: Sosial dan Modernisasi Ekonomi dua Kota Indonesia". Jakarta. P.T. Gramedia

Fitria, N. T. (2017). BISNIS JUAL BELI ONLINE (ONLINE SHOP) DALAM HUKUM ISLAM DAN HUKUM NEGARA. Jurnal Ekonomi Islam , 52.

Munir, S. (2017). JUAL BELI ONLINE MENURUT PANDANGAN ISLAM. Al-Daulah, 371.

Pekerti, D. R. (2018). Transaksi Jual Beli Online dalam Prespektif Syariah Madzhab AsySyafi'i. Jurnal Ekonomi, Bisnis, dan Akuntansi, 3. 